МЕДІАКУЛЬТУРА

Visn. Lviv. Univ., Ser. Zhurn. 2020: 47; 132-142 • DOI: http://dx.doi.org/10.30970/vjo.2020.47.10512

УДК $82(477)$ "18/19" : 801.73

\title{
ГЕРОЇЗМ ЯК ЕСТЕТИКО-ГЕРМЕНЕВТИЧНИЙ КОНЦЕПТ У ПУБЛІЦИСТИЦІ 20-30 РОКІВ ХХ СТОЛІТТЯ
}

\author{
Вікторія Колкутіна \\ Національний університет «Одеська юридична академія», \\ вул. Фонтанська дорога, 23, 65009, Одеса, Украӥна \\ e-mail:kolkutinav@ukr.net \\ https://orcid.org/0000-0002-3823-8415
}

Предметом нашого дослідження є тлумачення героїзму як естетико-герменевтичного концепту в українській публіцистиці 20-30 років XIX століття на матеріалі есеїстки Дмитра Донцова. Виявлено, що героїзм розкриває свою сутність у контексті суголосних ідей: елітаризм (лицарськість), історизм, окциденталізм, активізм (чинність), пов'язаних з поняттями жертовного патріотизму, романтизму, готики, національної свідомості тощо.

Ключові слова: Дмитро Донцов, герменевтика, героїзм, публіцистика, есе.

\section{Постановка проблеми}

Актуальність теми зумовлена прагенням дослідити сутність та специфіку одного $з$ найсучасніших концептів сьогодення - героїзм, який з огляду на суспільно-політичні катаклізми й протиріччя потребує, на наш погляд, цілісної аксіологічної інтерпретації й тлумачення. Вважаємо, що наочніше та доцільніше було б простежити його, звернувшись до найяскравіших прикладів минулого, яке, як справжній цінний історичний досвід, живить сучасність та мусить надихати прийдешні покоління до боротьби та небайдужості. Відтак, звернення до публіцистики націософського герменевта та філософа Дмитра Донцова допоможе віднайти ті ключові сегменти, які, щиро у цьому переконані, змусять сучасний політикум та у цілому різномисляче суспільство до розмислення над складнощами вибору майбутнього країни, над доцільністю вже обраного шляху, щоб зорієнуватися, яким історичним шляхом їй крокувати, з метою протидії націоруйнівним стратегіям і практикам культурного імперіалізму та космополітизму, зокрема в контексті російсько-української війни.

Mema cmammi - у націософському аспекті протрактувати героїзм як естетико-герменевтичний концепт у публіцистиці 20-30 років XX століття, зокрема на матеріалі літературно-критичних есе Дмитра Донцова «Поетка українського Рисорджименто (Леся Українка)», «Провідна верства козацька у І. Котляревського», «Геть-

(C) Колкутіна В., 2020 
ман Мазепа в європейській літературі», «Пам’яті великого вигнанця», «В мартівську річницю», «Козак із міліонна свинопасів».

Відтак, завданням роботи вбачаємо дослідження основних складових цього поняття: елітаризм (лицарськість), історизм, окциденталізм, активізм (чинність), пов'язаних з поняттями жертовного патріотизму, романтизму, готики, національної свідомості тощо.

Аналіз останніх досліджень та публікацій

У наш час у літературознавстві ми простежуємо чималу кількість написаного про Д. Донцова - грунтовні роботи О. Багана, В. Іванишина, Г. Сварник, С. Квіта, П. Іванишина, в яких раз від разу йшлося про найважливіші його герменевтично-методологічні ідеї (націоцентризм, ідеалізм, волюнтаризм, героїзм), проте саме героїзм не був вилучений і концептуально потрактований.

\section{Методи та методики дослідження}

При вирішенні поставлених завдань домінантним, наскрізним методом стала герменевтика (передусім метод націософської (націоекзистенційної) інтерпретації). У ході залучення цього методу були виявлений провідні сегменти героїзму як естетичного концепту у публіцистиці Д. Донцова. Націоналістична інтерпретація у суті своїй націологічна (націософська), але водночас і літературознавча $з$ типовим для таких досвідів переважанням когерентно-смислового рівня пізнання й оцінки над формально-естетичним, що дало змогу нам вивчити героїзм як четверту основна інтерпретаційна ідея в національно-екзистенційній герменевтиці Д. Донцова, що тісно пов'язана з його системою неоромантичної, героїчної естетики «трагічного оптимізму» та ідеалістично-волютаристичною філософією загалом.

Завдяки цьому методу перед нами відкрилась перспектива змоделювати волюнтаристську світоглядну систему, котра репрезентована сегментами, що мають власні розмежування: «волі» («воля до влади», «воля до життя»), романтичного ірраціоналізму, натхнення (рецепція Середньовіччя; універсалізм; творча наснага), інтуїтивізму. Вони відповідають засадам націоналізму, бо у такий спосіб повертають українців до власного національного буття, налаштовують їх на національне реанімування духовності.

\section{Виклад основного матеріалу дослідження}

У контексті націософської герменевтики Д. Донцова героїзм як опорна естетико-методологічна ідея оголює національну сутність присутності як буття-до-смерті, сприяе осмисленню філософсько-онтологічних питань життя і смерті, і в такий спосіб нівелює смерть як фізичний кінець власного чи колективного буття-у-світі. Він найчастіше проявляє себе як лицарськість. Наприклад, щоб підкреслити мораль аристократів духу, Д. Донцов, досліджуючи творчість Лесі Українки («Поетка українського Рисорджименто (Леся Українка)»), пише: «Левіт у драмі "На руїнах" проголошує: “Закон потрібний людям для закону, як Бог для Бога. Ми його раби і мусимо йому служити сліпо!” Це ж була мораль Середньовіччя [...] послух волі Божій, що змушував тисячі хрестоносців кидати майно й родину і гонити на край світу визволяти Гріб Господинь [...] була це кров, проллята тими ж лицарями хреста в Палестині. Екстаза аскета і звеличення героїчних імпульсів людської природи».

' Донцов, Д. (2003), Туга за героӥчним. Постаті та ідеї літературної України, Веселка, Київ, с. 31. 
Так виникає важливий середньовічний модус - жертовний патріотизм, зумовлений любов’ю до своєї країни, вірою у свій народ. Д. Донцов порушує проблему добровільної жертви в поезії Лесі Українки. У семантичній структурі середньовічний сегмент «добровільна жертва» позначений антонімічними асоціаціями, пов'язаними 3 біблійною символікою: добровільна жертва - це не покора. Наприклад, на матеріалі драми «Три хвилини», поезії «Завжди терновий вінець» він резюмує: «кров, пролита в боротьбі, - лише має викупляючу силу для нації й ідеї. Сама ж ідея - так як розуміли іï сучасники, не підперта чином і жертвами, для поетки - $є$ ніщо. Але ій імпонує лише добровільна жертва, терпіння, натхнене великою ідеєю, коли свідомі свого посланництва morituri - "по волі квітчаються терном". Для неї "путь на Голгофу велична (лиш) тоді, коли тямить людина, на що й куди вона йде!”» (курсив наш. $-B . K.)^{2}$.

3-поміж поетичної та драматургічної спадщини письменниці Д. Донцов «віднайшов» близьку його ідеологічній концепції активну особистість, котрій притаманний дух незламності, сильна воля, владність й усвідомлення свого виняткового призначення. Ідеалом борця за незалежність у Д. Донцова виступає «середньовічний лицар, який уважав себе негідним ласкавого погляду дами, коли не міг покласти їй до ніг бодай кількох трупів зухвальців, які сумнівалися в красі і чеснотах його обраниці» ${ }^{3}$ У такий спосіб розгортається романтична парадигма Д. Донцова, яка, очевидно, певною мірою суголосна з гоголівською поетизацією Середньовіччя. М. Гоголь також підкреслював пристрасний, зухвалий, бунтарський характер людських прагнень у середні віки. Середньовіччя для письменника (як і згодом для Д. Донцова) - це час колосальних подій, гігантських відкриттів, полум'яних пристрастей, зухвалих мрій та звершень ${ }^{4}$.

Героїчні ідеали Д. Донцова завжди закорінені в історичній традиції. У світогляді людей Середньовіччя Д. Донцов бачив зразок для наслідування: його сучасники повинні репрезентувати ідею virtus, жити нею, завжди ставити національні ідеї вище за власні. 3 такою метою він культивував активну особистість, небайдужу, що свідомо йде на жертву, на самозречення заради високих ідей. Потужний віталізм вольової людини, на думку дослідника, увиразнено завдячує романтичному натхненню. Натхнення зумовлює протест людини проти відчуженої, пригніченої, такої, що руйнує людську особистість, дійсності, спрямовує до піднесеного ідеалу, витоки якого вже були в історії. Середні віки для мислителя - надійний дороговказ для тих, хто, відкинувши приватні інтереси, став, охоплений натхненням, на шлях активної боротьби за реалізацію найвищих цінностей.

У проекціях історико-політичних та культурологічних подій та зрушень України Д. Донцову імпонувала мета нового Відродження в Італії - визволення італійських територій, об’єднання роздробленої держави, заохочення науки, літератури, мистецтва, сприяння всіма можливими засобами духовному й політичному об'єднанню країни, про яке мріяв ще Данте, до світогляду і творчості якого він неоднора-

\footnotetext{
2 Донцов, Д. (1994), «Поетка украӥнського Рісорджіменту (Леся Українка»)», Украӥнське слово: У 3 m., Рось, Київ, т. 1, с. 154.

3 Загребельний, I. (2011), «Ідеал Середніх віків у творчості Дмитра Донцова», Гілея, вип. 52. с. 28.

4 Карташова, И. (1974), Вопросы искусства в творчестве Гоголя 1 половины 30 годов, Калининский ун-т, Калинин, с. 61-62.
} 
зово звертатиметься («Пам’яті великого вигнанця», «Про молодих», «Поетка українського Рисорджименто (Леся Украӥнка)»).

Період нового відродження в Італії сягав початку XIX століття і проходив під гаслом романтичного світогляду5 ${ }^{5}$ Найбільшим виразником цієї нової ідеології став відомий міланський журнал «Кончильяторе». У статтях літературного критика Ермеса Віконті, поета Джованні Берше, філософа Д. Романьозі, драматурга Сильвію Пелліко обгрунтовувалася думка про нерозривний зв'язок літературної справи з громадською (letterario-civile), що стала однією з провідних ідей століття 6 .

Ентузіасти «Кончильяторе» намагались включити Італію до загальноєвропейського культурного руху, подолати її замкненість та відсталість. Саме культура відігравала винятково важливу роль у справі забезпечення мистецьких, патріотичних та естетичних потреб італійської національної спільноти. У цьому полягала одна 3 характерних рис національно-історичного розвитку Італії. Головним завданням літератури та мистецтва італійські романтики вважали виховання національної свідомосmi. Вони означили нову літературу передусім як «літературу дійсності», повсякчас підкреслюючи необхідність правдивого відображення життя у творах літератури та мистецтва7. Така думка була органічно близькою ідеології українського мислителя. Д. Донцова та відомих діячів італійського відродження Дж. Берше, Е. Віконті і особливо А. Мандзоні споріднювало спільне уявлення про мету письменства - віддзеркалення й осмислення долі свого народу, уміння вчасно вловити й порушити в літературі найважливіші проблеми народного життяв .

Центральними персонажами художніх творів мають стати ideaльні герої, які б могли служити сучасникам взірцями мужності й вірності революційному ідеалу. Можливо, тому Дж. Берше, Е. Віконті, А. Мандзоні особливо опікували суспільно-політичну лірику, що мала сугестивну, єднальну силу та впливала на формування молодого покоління. Така трансформація уможливлювала появу й ідеалізацію головного героя - символу ідей автора, наділеного непохитним характером, міцними ідейними переконаннями, шляхетністю й душевним благородством, безстрашною ризикованою натурою. Герої ранніх романтиків, як і персонажі донцовського дослідження, - це носії відповідних ідей, за М. Бахтіним, - «виразники ідей». Д. Донцов порушує питання протиставлення в художніх творах ідеалів особистості й маси.

Д. Донцов як літературний герменевт ідеалізує, підносить характери, типи, риси, завзяття, засади козаччини й гетьманщини, бо «кожна історична доба відбивається в письменстві своїм стилем і світоглядом, типами і дієвими особами. Старокиївська доба в нашім письменстві була епосом лицарства і літератури морально-релігійної. Подібно доба козацько-гетьманська»9. Так формується ідеал провідної козацької верстви ${ }^{10}$ ідеал провідника-характерника ${ }^{11}$, лицаря, що «гонить світами за

\footnotetext{
5 Баткін, Л. (1975), «Про італійське відродження», Всесвіт, вип. 7, с. 182-199.

6 Парфенчук, Н. В. (2008), «Духовна культура епохи Рисорджименто як двигун політичного об’єднання країни», Вісник Черкаського університету. Суспільні науки, вип. 5, с. 56.

7 Сказкин, С. (1971), История Италии, Наука, Москва, с. 494.

8 Рутенбург, В. (1980), Истоки Рисорджименто: Италия в XVII-XVIII вв., Наука, Ленинград, c. $55-56$.

9 Донцов, Д. (2010), Літературна есеїстика, Відродження, Дрогобич, с. 330.

10 Там само, с. 347

${ }^{11}$ Там само, с. 352.
} 
своїм ідеалом, своєю химерою, фантомом»12. Функціонування цього ідеалу неможливе без обов'язкової проекції на сучасність, яка в архітектоніці його статей почасти виступає завершальною частиною. Наприклад, розвідка «Провідна верства козацька у I. Котляревського» закінчується пересторогою: «Дуже актуальна поема - "Енеїда" в наші дні, які криком кричать за новими Енеями Котляревського, які імперативно вимагають усунути 3 провідних становищ сьогоднішніх Латинів чи Турнів, які особливо перші - в постаті Шейків нахабно хапають своєю плебейською рукою за керму національного корабля» ${ }^{13}$.

На думку мислителя, прагнучи прочитати і донести історію свого народу як славу і катастрофу водночас, Т. Шевченко та Леся Українка трактують іiї у принципово новому ключі - як нереалізовану можливість, що зумовило іiї історичну відсталість - втрату національної ідеї як джерела культурно-історичної динаміки національного буття. Генератором такої ідеї, на думку Д. Донцова, виступає українська суспільна еліта, що забезпечує всебічний розвиток та актуалізацію сутнісного потенціалу українства.

Звернення Д. Донцова до елітаризму є логічним, адже він захоплювався теорі$є ю$ еліт В. Парето чи В. Липинського та керувався власною основною метою - створення національної української держави, що було сенсом його життя і найвищою духовного цінністю. Розбудувати національну державу можна за умови, коли в соціумі існують вищі соціальні верстви, котрі зацікавлені в її існуванні.

Філософ подає власне визначення, згідно з яким еліта формується з найкращих представників, незалежно від соціального статусу. 3 моменту самоусвідомлення їх елітою за критеріями волюнтаризму, волі до влади, енергійної динамічної працелюбності вони перетворюються на «правлячу верству». Еліта («вождівство»» $)$ у потрібний спосіб має визначати ідеологічну стратегію держави, й від її вмілого керування («умом і храбрістю» ${ }^{15}$ ) залежать «настрої» мас та, відповідно, стабільність суспільства. Д. Донцов усвідомлював, що формування національної самосвідомості - це тривалий, суперечливий процес, детермінований як чинниками соціоісторичного буття, так і зміною самоідентифікації еліти, роль якої у націєтворчій розбудові він не применшував.

Прикладом такої взірцевої особи у ранній літературній публіцистиці є постать Івана Мазепи («Гетьман Мазепа в європейській літературі»), що відстоював право на власне націотворення. Цю ідею Д. Донцов «прищепив» до потреб свого суспільства, водночас ідентифікувавши гетьмана як виїмкову постать, досвідченого політика, що не цурається персональної відповідальності за свої дії. У такої людини відчуття глибокої спорідненості зі своїм народом та нацією органічно поєднані з бажанням діяти, вимогливо ставитися до своїх обов'язків, перейматися майбутнім своєї країни. Свідомо зробивши вибір на користь національної ідеї, гетьман осмислив перспективи окремішності та вільного шляху нації. За Д. Донцовим, Мазепа і $є$ самосвідомою особистістю, яку історичний виклик змусив шукати адекватної відповіді.

\footnotetext{
${ }_{12}$ Там само, с. 353

13 Там само, с. 358

14 Там само, с. 351.

15 Там само, с. 352.
} 
Д. Донцов у націоцентричному сенсі культивує сильного, вольового, інтелектуально-розвиненого індивіда в національній історії. Його мета - знайти зразкового державника європейського рівня та на прикладі неоднозначно висвітленої, але сильної особистості в літературі й історії довести, що вони потребують наслідування. Першорядного значення набувають романтичні ознаки справжнього гетьмана: благородство, мужність, мудрість, міць, які були притаманні українській князівській, литовсько-руській і козацькій аристократії. Есеїст дотримується теорії ієрархічного суспільства - провідної пануючої верстви ${ }^{16}$.

Стаття «Гетьман Мазепа в європейській літературі» перегукується з працею «Дух нашої давнини» (1943), у якій окреслено основні чесноти правлячої касти: героїзм, віру у своє високе призначення, відданість справі, честь і відвагу. Осібне місце посідає в цьому переліку категорія сили, яка реалізується через рух, потяг, вічне прагнення йти вперед. Аналітичні ознаки властиві романтичному типу художнього мислення. Провідна верства, втративши ці якості, нівелюється, а тоді й зникає національна ідея, розпадається й гине держава.

Д. Донцов пояснює дихотомію каяття/некаяття у світогляді та творчості Т. Шевченка. Таким масштабним цілісним підходом (враховуючи світоглядну та творчу спадщину) публіцист розкриває прояви непокаянної поетової свідомості, досліджує глибоко психологічний стан некаяття. Д. Донцов стверджує, що каятися - значить бути «невільником».

Героїзм пов’язаний з таким самобутнім явищем в українській історії, як Запорозька Січ, з героїкою «несмертельних типів січовиків» ${ }^{17}$, «джентельменів нації», «втілення найкращих національних прикмет, предмет пошани і подиву для своїх i нейтральних чужинців, предмет ненависті для займанців, а для маси - зразок, який старались наслідувати» ${ }^{18}$. Крізь призму художніх творів Січ поставала як соціальне утворення, що об’єднує вільних козаків-богатирів, оспіваних в оповіданнях, легендах і народних переказах «людей-велетів» ${ }^{19}$. Цей поетичний феномен увиразнив характер українських героїв і войовників, підкреслив їхню романтичну «одчайдушність, відвагу, героїзм, релігійність, нахил до буйного розгулу, до медитації, до сарказму, до речей великих» (про це у нашій докторській дисертації «Літературна есеїстика Дмитра Донцова: націософсько-герменевтичні аспекти», Дрогобич, 2018, с. 186).

Ретроспективне поглиблення в минулі історичні часи, осмислення історії в такому вимірі - це літературознавчий методологічний прийом, за допомогою якого есеїст культивує потребу «нової української людини» у звитязі, хоробрості, змаганні. Героїчна етика й культ героїв - невід’ємні важливі складові ідеології українського націоналізму. У такому історіософському контексті реалізовані духовні прояви націоналізму, духовність особистості, героїчна духовність як пряме вираження національного світобуття, національного самопізнання через усвідомлення й осмислення екзистенційних категорій, бо героїзм невіддільно пов'язаний 3 категорією життя i смерті, злету й падіння, а минуле трансформується в літературознавчий естетично-філософський концепт, котрий функціонально вказує на місіонерське призначен-

\footnotetext{
${ }_{16}$ Там само, с. $527-545,498-522$.

${ }_{17}$ Там само, с. 370.

18 Там само, с. 331.

${ }^{19}$ Там само, с. 341.
} 
ня того чи іншого героя або письменника. Більше того, героїзм зумовлює відбір тем, мотивів, сюжетів, визначає і впливає на характер й інтерпретацію образності.

Призначення літератури як «духовної науки» (В. Дільтей) реалізується в істоpuзмi - охопити, осягнути та потрактувати історичну дійсність, збагнути кожну подію, розшифрувати кожен історичний факт, на наш погляд, наочно представлений у літературно-критичній практиці Д. Донцова.

Значущість героїзму зумовлюється і переживанням як предметом, як знаком духовної діяльності, як своєрідним каналом, через який Д. Донцов як літературний герменевт «переводить» переживання за долю держави героїчних постатей (наприклад, того ж Івана Мазепи) всередину - як частину своєї власної сутності, тим самим заохочуючи співвітчизників «перевести» героїчні випробування всередину власного буття, пережити таке ж героӥчне життя як можливість перетворитися, оновитися й самовдосконалитися. Такий психолого-інтерпретаційний метод веде до загальнозначущого розуміння історичного знання в описовій психології В. Дільтея, котрий активізував переживання через упредметнення («Побудова історичного світу в духовних науках»).

Через переживання, за В. Дільтеєм, людина переходить зі світу фізичних явищ у річище духовної дійсності: «Знання про духовний світ людини виникає із взаємодії переживання, розуміння інших людей, історичного осягнення спільнот як суб’єктів історичної дії і, зрештою, об'єктивного духу. Переживання - це фундаментальна передумова всього цього» ${ }^{20}$. Німецький філософ виокремлює тріаду, засновану на відношенні «переживання-вираження-розуміння», яка, на нашу думку, знаходить своє втілення в літературній герменевтиці Д. Донцова як можливість інтерпретації світу героїчної людини (у В. Дільтея просто «світу людини») засобом самоосмислення своєї ролі в історичному перебігу подій, як потенціальний перехід - а далі й тотожність духу «Я» (пересічної особистості) у дух «Ти» (духовно піднесеної героїчної постаті). Цей духовний первень, обумовлений індивідуальністю й історичністю, визначає достовірність героїчного поступу, подвигу, вчинку, акції як особисто пережитого, усвідомлення героїчною людиною особливої цінності історичної події в її досвіді. Така модифікація світу індивідуума в рецепції Д. Донцова надає суб'єктові значущості якраз через взаємопроникнення, взаємозв'язок «духовних наук». Тобто, Д. Донцова як герменевта цікавить переживання не як внутрішній прояв пережитого, не як уболівання за власні інтереси, добробут, цінності, а в значенні вираження участі героїчної постаті в історичному процесі життєздійснення як націєствердження. Отже, героїзм виокремлюємо як «формальну категорію» (В. Дільтей), котра модифікується, доповнюється моментами героїчного життєвияву й духовного самоосмислення.

Ще одним поняттям, важливим для витлумачення методологічної продуктивності ідеї героїзму, стає окциденталізм. Оскільки саме Європа (і породжений нею Окцидент) $є$ для Д. Донцова унікальним культурним континентом, населеним «незвичайною расою людей», расою, для котрої «світ є гра пригод, безнастанний підбій», для котрої «найвищою цінністю є чин, а світ - спортовою ареною», для якої основною тугою все була «туга за великим призначенням». I тому в літературі Окциденту скрізь можна знайти основні риси європеїзму, наснаженого «духом героїз-

20 Дильтей, В. (1988), «Наброски к критике исторического разума», Вопросы философии, вип 4. c. $135-152$. 
му», духом «змагання, росту і перемоги» ${ }^{21}$. Не випадково дослідники вказують на архетипний образ Римського Легіонера як персоніфікацію європейського героїзму для філософа, уособлення «сили і динаміки, лицарства і благородства в історії», цей «вічний воїн і спокійний герой, що вистояв у пущах Галлії і Германії, в пустелях Африки і Арабії, на плоскогір'ях Еспанії і Вірменії - дисциплінований, суворий, завжди націлений на здобування і випробування» ${ }^{22}$.

Ще однією важливою складовою європейського, а значить українського, героїзму є активізм (чин). Методологічна ідея активізму в Д. Донцова суголосно із Г. Кайзерлінгом базується на філософії життя як волі до чину, на філософії життя як боротьби: «Бо поступ родиться лише з прагнення життя, з волі чину, посідання, з огнистої жадоби скорити собі світ» ${ }^{23}$. Ця філософія споріднена 3 гегелівською філософією неспокою, котра часто проявляє себе як власне героїзм, як абстрактна «втіха» повставати проти будь-якої чужої волі: «Герой або накидає свою волю оточенню, перемагає, або не приймає сього оточення, не дає йому зігнути свою безсмертну волю, не хилиться перед ним і гине, але не визнає чужої волі над собою. Він із самолюбних мотивів шукає смерти, воліючи їі, ніж упокорення перед зненавидженим оточенням. Часто-густо він вигадує собі різні мотиви своїх героїчних учинків, але сі мотиви не $є$ їхнім джерелом». Тут філософ підтримує думку Ф. Ніцше про те, що воля може стати дійсністю «тільки через негацію, через боротьбу ${ }^{24}$. Не випадково одну 3 найхарактерніших рис героїчного характеру Дон Кіхота мислитель витлумачує як «містику чину», як певну «самоціль» 25.

Закономірно, що в системах художньої філософії, естетики та герменевтики вісниківства утверджується героїчний ідеал Т. Шевченка - життя як боротьби: «У поезії, прозі, літературній критиці “вісниківство”, намагаючись нав’язати наші історичні традиції до давніх, висунуло ідеал життя як боротьби, а не капітулянтства, ідеал своєї Правди, а не пристосовування себе до чужої, ідеал людини, вільної духом, твердого характеру, фанатика своєї ідеї, людини не літеплої, а гарячої віри, сильної й відважної» ${ }^{26}$. Однією з найхарактерніших персоніфікацій національної активістичної традиції і водночас зразком для новітніх провідників народу, еліти стає князь Святослав - «аскет і герой», чий світогляд скерований до ідеального, величного, до напруги й боротьби: «Люди, подібні до Святослава, повинні на Україні повстати, які ненавидять усе те, що дороге плебеям, і люблять усе те, що тим огидне. Які ненавидять ідилію і спокій особистого щастя і тілесних насолод “простих людей”, які над “муравлину працю” знають працю вищого роду, які постачають людству не "ловців риби” чи продуцентів збіжжя, а “ловців людей”, які прив’язані не до земного, а до

\footnotetext{
${ }_{21}$ Донцов, Д. (2009), «Росія чи Європа? (До літературної суперечки)». Донцов, Д., Літературна есеїстика, Відродження, Дрогобич, с. 266.

22 Баган, О. (2012), «В обороні української цивілізації», Баган, О, Культурологічна та історіософська есеїстика (1911-1939 рр.), Відродження, Дрогобич-Львів, т. 2., с. 13.

${ }^{23}$ Донцов, Д. (1958), «Криве дзеркало нашої літератури», Донцов, Д., Дві літератури намої доби, Гомін України, Торонто, с. 277.

24 Донцов, Д. (2014), «Націоналізм», Баган, О., Ідеологічна та історіософська есеїстика (19231939 рр.), Відродження, Дрогобич, с. 122, 127.

25 Донцов, Д. (1958), «Санчо-Панца в літературі і в життю». Донцов, Д., Дві літератури намої доби, Гомін України, Торонто, с. 130.

26 Донцов, Д. (2015), «Демаскування шашелів», Баган, О, Ідеологічна і культурологічна есеїстика (1948-1957 рр.), Відродження, Дрогобич, с.82-83.
} 
ідеального, які захоплюються не гарним, а величним, а щастя шукають не в розпряженню та ідилії, а в напрузі й у боротьбі» ${ }^{27}$.

Результати і перспективи подальших досліджень обговорення

Отже, ми розглянули героїзм як одну з основних інтерпретаційних ідей у національно-екзистенціальній герменевтиці Д. Донцова. Вона тісно пов’язана з системою неоромантичної, героїчної естетики «трагічного оптимізму» мислителя та його ідеалістично-волютаристичною філософією загалом. Попри складну еволюцію (від соціалізму через консерватизм до націоналізму) Д. Донцов завжди в суспільно-політичній та етичній сферах утверджував вартості та принципи «громадянського героїзму», котрий «сповнений високого ідеалізму і логічного максималізму, романтичної світлости і шляхетної наступальности, він завзятий і категоричний, свідомий великої відповідальности за минуле і майбутнє, за світове і національне» (О. Баган).

\section{Висновок}

Загалом, героїзм як естетико-герменевтичний концепт розкриває свою сутність у контексті суголосних ідей: елітаризм (лицарськість), історизм, окциденталізм, активізм (чинність), пов’язаних з поняттями жертовного патріотизму, романтизму, готики, національної свідомості тощо.

\section{СПИСОК ЛІТЕРАТУРИ}

1. Баган, О. (2012), «В обороні української цивілізації», Баган, О, Культурологічна та історіософська есеїстика (1911-1939 рр.), Відродження, Дрогобич-Львів, т. 2., c. $5-15$.

2. Баткін, Л. (1975), «Про італійське відродження», Всесвіт, вип. 7, с. 182-199.

3. Загребельний, I. (2011), «Ідеал Середніх віків у творчості Дмитра Донцова», Гілея, вип. 52. с. 23-28.

4. Дильтей, В. (1988), «Наброски к критике исторического разума», Вопросы философии, вип 4. с. 135-152.

5. Донцов, Д. (2015), «Демаскування шашелів», Баган, О, Ідеологічна і культурологічна есеїстика (1948-1957 рр.), Відродження, Дрогобич, с.81-101.

6. Донцов, Д. (2015), «Заповіт Святослава та ідилічні смерди», Баган, О., Ідеологічна i культурологічна есеїстика (1948-1957 рр.), Відродження, Дрогобич, с. 242-250.

7. Донцов, Д. (1958), «Криве дзеркало нашої літератури», Донцов, Д., Дві літератури нашої доби, Гомін України, Торонто, с. 259-278.

8. Донцов, Д. (2010), Літературна есеїстика, Відродження, Дрогобич, 688 с.

9. Донцов, Д. (2014), «Націоналізм», Баган, О, Ідеологічна та історіософська есеїстика (1923-1939 рр.), Відродження, Дрогобич, с. 19-179.

10. Донцов, Д. (1994), «Поетка украӥнського Рісорджіменту (Леся Украӥнка»)», Українське слово: У 3 m, Рось, Київ, т. 1, с. 149-183.

11. Донцов, Д. (2009), «Росія чи Європа? (До літературної суперечки)». Донцов, Д., Літературна есеїстика, Відродження, Дрогобич, с. 265-284.

12. Донцов, Д. (1958), «Санчо-Панца в літературі і в життю». Донцов, Д., Дві літератури нашої доби, Гомін України, Торонто, с. 124-153.

27 Донцов, Д. (2015), «Заповіт Святослава та ідилічні смерди», Баган, О., Ідеологічна і культурологічна есеїстика (1948-1957 рр.), Відродження, Дрогобич, с. 249. 
13. Донцов, Д.(2003), Туга за героӥчним. Постаті та ідеї літературної Украӥни, Веселка, Київ, 101 с.

14. Карташова, И. (1974), Вопросы искусства в творчестве Гоголя 1 половины 30 годов, Калининский ун-т, Калинин, с. 57-73.

15. Парфенчук, Н. В. (2008), «Духовна культура епохи Рисорджименто як двигун політичного об'єднання країни», Вісник Черкаського університету. Суспільні науки, вип. 5, с. 56-59.

16. Рутенбург, В. (1980), Истоки Рисорджименто: Италия в XVII-XVIII вв., Наука, Ленинград, 303 с.

17. Сказкин, С. (1971), История Италии, Наука, Москва, 605 с.

\section{REFERENCES}

1. Bagan, O. (2012), "In defense of Ukrainian civilization”, in. Bagan, O., Cultural and historical philosophical essay (1911-1939 years ), Renaissance, Drohobych-Lviv, vol. 2, $5-15 \mathrm{p}$.

2. Batkin, L. (1975), “About the Italian Renaissance”, Universe, vol. 7, pp. 182-199.

3. Zagrebelnyj, I. (2011), "The Ideal of the Middle Ages in the Works of Dmitry Dontsov", Gilea, vol. 52, pp. 23-28.

4. Dyltej, V. (1988), "Outline to the Critique of the Historical Reason", Questions of philosophy, vol.4, pp. 135-152.

5. Donczov, D. (2015), "Unmasking the barbecue", in. Bagan, O., Ideological and Cultural Studies (1948-1957 years), Renaissance, Drohobych, 81-101 pp.

6. Donczov, D. (2015), "Will Svyatoslav and idyllic deaths", in. Bagan, O., Ideological and Cultural Studies (1948-1957 years ), Renaissance, Drohobych, 242-250 pp.

7. Donczov, D. (1958), "Curve mirror of our literature", Donczov, D., Two literatures of our era, Gomin Ukraine, Toronto, 259-278 pp.

8. Donczov, D. (2010), Literary essay, Renaissance, Drohobych, 688 p.

9. Donczov, D. (2014), "Nationalism", in. Bagan, O., Ideological and Historio-philosophical Essay (1923-1939), Renaissance, Drohobych, pp.19-179.

10. Donczov, D. (1994), "Poetry of the Ukrainian Resource Management (Lesya Ukrainka)", Ukrainian word: In $3 t$, vol. 1, pp. 149-183.

11. Donczov, D. (2009), "Russia or Europe? (To the literary dispute). Donczov, D. Literary essay, Renaissance, Drohobych, pp. 265-284.

12. Donczov, D. (1958), Donczov, D., Two literatures of our era, Gomin Ukraine, Toronto, p. 124-153.

13. Donczov, D. (2003), Longing for heroic. Figures and ideas of literary Ukraine, Rainbow, Kiev, $101 \mathrm{p}$.

14. Kartashova, Y. (1974), Issues of art in Gogol's work in the first half of 30 years, Kalinin Univ, Kalinin, pp. 57-73

15. Parfenchuk, N. V. (2008), "The spiritual culture of the Risorgimento era as the engine of political unification of the country", Bulletin of Cherkasy University. Social science, vol. 5, pp. 56-59.

16. Rutenburg, V. (1980), Origins of Risorgimento: Italy in the 15th-15th centuries, Science, Leningrad, $303 \mathrm{p}$.

17. Skazkyn, S. (1971, History of Italy, Science, Leningrad, 605 p. 


\title{
HEROISM AS AN AESTHETIC-HERMENEUTIC CONCEPT IN JOURNALISM OF THE 20-30 YEARS OF THE TWENTIETH CENTURY
}

\author{
Viktoriya Kolkutina \\ National University "Odessa Law Academy», \\ Fontanskaya road, 23, 65009, Odessa, Ukraine \\ e-mail: kolkutinav@ukr.net \\ https://orcid.org/0000-0002-3823-8415
}

In the history of Ukrainian literature of the twentieth century, there is a marked difference in the news of «a supratemporal phenomenon» (O. Bagan). At the heart of this vivid socioideological and cultural-aesthetic phenomenon lies the work of the outstanding political philosopher, public figure, publicist, essayist, editor, publisher, literary critic, ideologue of strong-willed nationalism Dmitry Dontsov (1883-1973). The role played by this thinker as a protagonist in the history of national culture is not by chance commensurate with the role and importance of the Italians Giuseppe Mazzini and Pasquale Mancini, the Spaniards Miguel de Unamuno and José Ortega y Gasset, the Englishmen Gilbert Keeston and Thomas Stearns Eliot, the Germans Johann Fichte and Oswald Spengler, the French Maurice Barre and Charles Morra, and others.

In the philosophy of $\mathrm{D}$. Dontsov, we observe a rather elaborate nationalistic aesthetics, the «Shevchenko's aesthetics» as a national theory of beauty in nature and art. The key features of this Shevchenko theory are heroism, nazi creation (the formation of the «spirit» of the nation and its elite), idealism (fundamental anti-materialism), mysticism (divinity, sacralism), vitality (existentiality, vitalism), spiritual creativity (human ennobling), uncompromising, adversarial (literature as a weapon), etc. It was this aesthetics that formed the basis of the hermeneutic method of the Ukrainian thinker.

Thus, we have considered heroism as one of the main interpretive ideas in the nationalexistential hermeneutics of D. Dontsov. It is closely linked to the system of neo-romantic, heroic aesthetics of the «tragic optimism» of the thinker and his idealistic-volaturistic philosophy in general.

Key words: Dmitry Dontsov, hermeneutics, heroism, journalism, essay. 